\title{
Redescription and biology of Cossura pygodactylata Jones, 1956 (Polychaeta: Cossuridae) in the White Sea
}

\author{
A.E. Zhadan, E.V. Vortsepneva, A.B. Tzetlin \\ White Sea biological station, Biological faculty, Moscow State University, Moscow 119234, Russia. \\ e-mail:azhadan@wsbs-msu.ru
}

ABSTRACT: Cossurids are quite abundant on soft substrata in the White Sea. Adult and juvenile specimens were studied using light and scanning electron microscopy. Originally the White Sea species was referred to Cossura longocirrata Webster et Benedict, 1887 but the present study revealed its affiliation to the close species C. pygodactylata Jones, 1956. Lateral organs are described for the first time in cossurids. Juveniles differ from adults by the presence of a prototroch, the pygidium without appendages, and hardly detectable division of the body into regions. Population size structure was investigated in four samples taken from July to November. Size-frequency histogram showed a bimodal distribution.

How to cite this article:Zhadan A.E., Vortsepneva E.V., Tzetlin A.B. 2012. Redescription and biology of Cossura pygodactylata (Polychaeta: Cossuridae) in the White Sea // Invert. Zool. Vol.9. No.2. P.115-125.

KEY WORDS: Cossura pygodactylata, Cossura longocirrata, taxonomy, juvenile development, size population structure, geographical distribution, Arctic.

\section{Переописание и биология Cossura pygodactylata Jones, 1956 (Polychaeta: Cossuridae) в Белом море}

\author{
А.Э. Жадан, Е.В. Ворцепнева, А.Б. Цетлин
}

Беломорская биологическая станиия им. Н.А.Периова, биологический факультет, Московский Государственный Университет имени М.В.Ломоносова, Москва, 119234, Россия e-mail:azhadan@wsbs-msu.ru

РЕЗЮМЕ: Полихеты семейства Cossuridae обычны и многочисленны на мягких грунтах в Белом море. Взрослые и ювенильные особи изучены с помощью световой и сканирующей электронной микроскопии. Изначально беломорские коссуриды были отнесены к виду Cossura longocirrata Webster et Benedict, 1887, однако настоящее исследование показало, что они относятся к близкому виду C. pygodactylata Jones, 1956. Впервые для коссурид описаны латеральные органы. Ювенильные особи отличаются от взрослых наличием прототроха, пигидием без придатков и трудноразличимым делением тела на отделы. Размерная структура популяций $C$. pygodactylata была изучена в четырех пробах, взятых с июля по ноябрь. Размерночастотные гистограммы показывают бимодальное распределение.

Как цитировать эту статью: Zhadan A.E., Vortsepneva E.V., Tzetlin A.B. 2012. Redescription and biology of Cossura pygodactylata (Polychaeta: Cossuridae) in the White Sea // Invert. Zool. Vol.9. No.2. P.115-125. 
КЛЮЧЕВЫЕ СЛОВА: Cossura pygodactylata, Cossura longocirrata, таксономия, развитие, размерно-популяционная структура, распространение, Арктика.

\section{Introduction}

Cossurids are a small group of polychaetes inhabiting at all depths, from shallow to deep waters, and generally in muddy sediments(Rouse, Pleijel, 2001). The family Cossuridae was erected by Day (1963) and includes a single genus, Cossu$\mathrm{ra}$ Webster et Benedict, 1887, with C. longocirrata Webster et Benedict, 1887 as type species; two other cossurid genera, Cossurella Hartman, 1976 and Heterocossura Wu et Chen, 1977, were synonymized with Cossura (Gardiner, Wilson, 1979; Read, 2000). At the present time the family Cossuridae consists of 23 species belonging to one genus Cossura. Cossurids are unique among polychaetes for having unpaired branchial filament and peculiar feeding apparatus; their eversible mouth tentacles are attached to the dorsal side of the buccal cavity (Tzetlin, 1994).

Representatives of the genus Cossura are common in the White Sea (WS) and abundant both in samples of meiobenthos (smaller specimens) and macrobenthos (adult specimens), taken on soft sediment from $20 \mathrm{~m}$ to maximum depths (300 m) (Naumov, Fedyakov, 2000). Data on the biology of Cossura in the WS are rather poor. Nothing is known about larval development, reproduction time and the duration of the life cycle.

Taxonomic affiliation of WS cossurids is not clear. Annenkova (1938) as well as subsequent authors (Zatsepin, 1948; Uschakov, 1955; Tzetlin, 1980) referred them to C. longocirrata; later Tzetlin \& Zhadan (2008) indicated the presence in the WS of the only species C.pygodactylata Jones, 1956. The present work aims at clarifying the taxonomic position of WS Cossura and at providing new data on morphology and biology of this species.

\section{Materials and Methods}

This study is based on the material collected during several cruises of RV "Kartezh" in the frame of a multidisciplinary study on the ecology and biology of the Central Basin of the White Sea (Central Basin Expedition- CBX) in 19982001. Material was collected by epibenthic sledge in the central part of Kandalaksha Bay of the WS on muddy sediment, at depths ranging from 30 to 277 m in July 1998, October 1998, November 1999 and August 2000 (samples 14 , Table 1). Samples were washed on a $100 \mu \mathrm{m}$ mesh, sorted under stereomicroscope and fixed in $10 \%$ formalin-seawater solution. Additional material (12 specimens) was collected in October 2011 (sample 5, Table 1), relaxed in isotonic $\mathrm{MgCl}_{2}$ solution and fixed with $2.5 \%$ glutaraldehyde solution on phosphate buffer. About 20 worms collected in July 2012 (sample 6, Table 1) were examined and photographed alive using Leica DFC420 stereomicroscope and Leica DM2500 light compound microscope with digital camera. The body width in the region of the brànchial filament was used for the size structure analysis; measurements were made using ocular reticule and rounded to the nearest 0.025 $\mathrm{mm}$; a total of 361 specimens were measured. For scanning electron microscopy (SEM) studies glutar-fixed specimens were dehydrated in rising series of ethanol-acetone solutions, dried using the critical point method, coated with platinum-palladium and examined with a Camscan S2 scanning electron microscope.

\section{Results}

Family Cossuridae Day, 1963

Genus Cossura Webster \& Benedict, 1887

Cossura pygodactylata Jones, 1956

Figs. 1-3.

Cossura pygodactylata Jones, 1956: 127, fig.1 a-f. Bachelet, Laubier, 1991: 358, 360, fig. 1 a,b, 2 a-f, 3 a-d.

The longest complete specimen is $350 \mu \mathrm{m}$ wide, about $6 \mathrm{~mm}$ long for 72 chaetigers. The 
Table 1. Characteristics of sampling stations. Таблица 1. Характеристика мест взятия проб.

\begin{tabular}{|c|c|c|c|c|}
\hline Sample № & Date & Depth, m & N latitude & W longitude \\
\hline 1 & 27.07 .1998 & 260 & $66^{\circ} 12^{\prime}$ & $34^{\circ} 22^{\prime}$ \\
\hline 2 & 14.10 .1998 & 112 & $66^{\circ} 22^{\prime}$ & $35^{\circ} 48^{\prime}$ \\
\hline 3 & 24.11 .1999 & 277 & $66^{\circ} 25^{\prime}$ & $34^{\circ} 22^{\prime}$ \\
\hline 4 & 08.08 .2000 & 30 & $66^{\circ} 52^{\prime}$ & $33^{\circ} 19^{\prime}$ \\
\hline 5 & 07.10 .2011 & 30 & $66^{\circ} 52^{\prime}$ & $33^{\circ} 19^{\prime}$ \\
\hline 6 & 25.07 .2012 & 30 & $66^{\circ} 52^{\prime}$ & $33^{\circ} 19^{\prime}$ \\
\hline
\end{tabular}

smallest juvenile is $140 \mu \mathrm{m}$ wide, $900 \mu \mathrm{m}$ long and has 14 chaetigers.

The description is based on about 30 adult and juvenile specimens studied in live conditions and using SEM. Living specimens are yellowish or tan; brown intestinal contents are seen due to transparency; chaetae are goldenbrown; red blood vessels are seen dorsally from the intestine and in the branchial filament (Fig. $1 \mathrm{G}, \mathrm{H})$. Preserved specimens are colorless. Body is slender, threadlike, divided into three regions. The prostomium is conical, without eyespots, two- three times longer than the peristomium, depending on the degree of contraction (Fig. 1A, B, D, G, H). Nuchal organs look like ciliated spots $10-15 \mu \mathrm{m}$ in diameter in relaxed state; they could be completely retracted (Figs 1A-D, $3 \mathrm{D}, \mathrm{E})$. The mouth opening is situated ventrally on the border of prostomium and peristomium (Figs 1B, 3D). One peristomial achaetous segment is present. The pharynx contains from 4 to 10 (always even number) eversible buccal tentacles covered by long cilia (Figs $1 \mathrm{~B}, \mathrm{G}, \mathrm{H}$, $3 \mathrm{E}, \mathrm{F})$; their number increases with size. The branchial filament is inserted on posterior border of the second chaetiger; it is longer than the body, with outer irregular rings; ciliary band begins at some distance from the base of the filament, and becomes intermittent in middle and distal parts (Figs 1A, B, D-F, 3A).
The thoracic region consists of 19-22 short chaetigers, their number increases with size. Parapodia are situated laterally close to anterior border of segments (Figs 1D, 2A, D). An area without segmental borders, sometimes (depending of contraction) with a medial shallow groove extends from branchial filament to the end of thorax on dorsal side; this area ("dorsal groove" of Fournier, Petersen, 1991) has no ciliation (Fig. 1A). In some specimens posterior thoracic segments have an additional transverse furrow and look biannulated (Fig. 1A). In the abdomen chaetigers become swollen and moniliform, parapodia are situated in the middle of segments (Fig. 2C). The abdomen consists of 35-40 segments. The posterior region consists of 7-10 short closely arranged segments, parapodia are located mid-laterally, and the last 1-2 segments are achaetous (Figs 2F, 3B, C).

The pygidium is cleft medially, with 3 long anal cirri and 8-14 shorter intercirral processes. Their length and number increase with age. Juveniles with 14-21 chaetigers have a smooth pygidium without any cirri or processes (Fig. 3B); a specimen with 30 chaetigers has 3 long cirri and 8 wide triangular processes (Fig. 3C); in larger specimens processes become longer, digitiform or pyriform (Fig. 2E-G). Two anal cirri are located dorso-laterally and one ventrally. Intercirral processes are arranged in two 

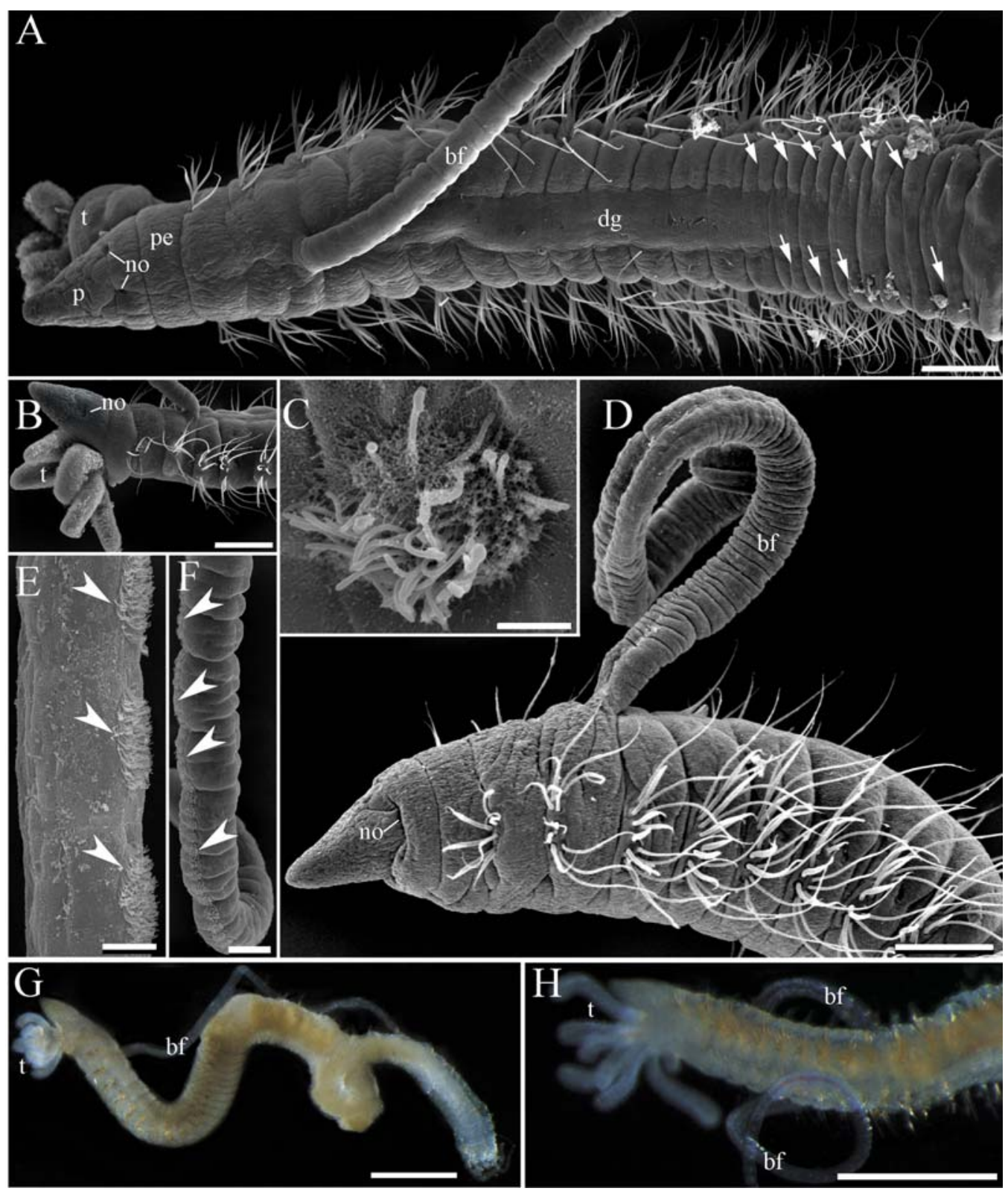

symmetric groups, each situated between dorso-lateral and ventral cirri (Fig. 2G).

Parapodial lobes are absent, chaetae arise directly from the body wall. All chaetigers bear lateral organs shifted posteriorly (Fig. 2C, D). They represent ciliated pits 4-6 $\mu \mathrm{m}$ in diameter (Fig. 2H).

All chaetae are hirsute capillaries with smooth shafts. The first chaetiger bears uniramous parapodia with 5-7 uniform chaetae (Figs 1B, D, 3A, D, E). All the next segments bear biramous parapodia. In the thoracic region notopodia have 4-7 chaetae, neuropodia 6-9 chaetae; chaetae are arranged in c-shaped row in each ramus, so they look as two rows (Fig. 2D). Chaetae differ by their width and length. This difference is stronger in neuropodia than in notopodia (Fig. 2A, D). The number and loca- 
Fig. 1. Cossura pygodactylata, adult specimens.

A-F - SEM, A - thorax and beginning of abdomen, dorsal view, arrows indicate additional tranversal furrows dividing segments; B — anterior part of the body, specimen with everted buccal tentacles, lateral view; C — nuchal organ; D anterior part of the body, lateral view; E-F — details of branchial filament, arrowheads indicate ciliated band; E median part, $\mathrm{F}$ - basal part; G-H - alive specimens, photos made with stereomicroscope, showing their coloration, lateral view. $\mathrm{G}$ - entire specimen; $\mathrm{H}$ - anterior end, blood vessel in the branchial filament is seen. bf - branchial filament, $\mathrm{dg}$ - "dorsal groove", no - nuchal organ, $\mathrm{p}$ - prostomium, pe — peristomium, t — buccal tentacles. Scales: A, B, D $-100 \mu \mathrm{m}, \mathrm{C}-3 \mu \mathrm{m}, \mathrm{E}-10 \mu \mathrm{m}, \mathrm{F}-30 \mu \mathrm{m}, \mathrm{G}, \mathrm{H}-500 \mu \mathrm{m}$.

Рис. 1. Cossura pygodactylata, взрослые особи.

A-F - CЭМ, А — вид со спинной стороны, торакс и начало абдомена, стрелки показывают дополнительные поперечные борозды, разделяющие пополам некоторые сегменты; В - вид сбоку, буккальные щупальца вывернуты; C — нухальный орган; D - передняя часть тела, вид сбоку; E-F — жаберный филамент, стрелки показывают ресничную полоску; Е - средняя часть, F - базальная часть; G-H - живые особи, вид сбоку, фото, сделанные на бинокуляре, показывают прижизненную окраску, G — целый экземпляр; Н — передняя часть тела, виден кровеносный сосуд в жаберном филаменте. bf — жаберный филамент, dg — “спинной желобок”, по нухальный орган, $\mathrm{p}$ - простомиум, pe - перистомиум, t - ротовые щупальца. Масштаб: А, B, D - 100 мкм, $\mathrm{C}-3$ мкм, E - 10 мкм, F - 30 мкм, G-H - 500 мкм.

tion of the different types of chaetae vary; as a rule thicker and shorter chaetae are situated in anterior row, and longer and thinner ones in posterior row (Fig. 2D). Thicker chaetae are about $4.6 \mu \mathrm{m}$ width, thinner chaetae are about $2.6 \mu \mathrm{m}$ width.

Notopodia bear 3-4 chaetae and neuropodia bear 4-5 ones in abdominal region; notochaetae are longer than neurochaetae (Fig. 2B, C). All chaetae are more or less uniform, although some can be thinner than others; thicker chaetae are about $2.7 \mu \mathrm{m}$ width, thinner chaetae are about $1.3 \mu \mathrm{m}$ width.

Morphology of juveniles. The smallest studied juveniles have 14 chaetigers ( $0.9 \mathrm{~mm}$ long), 18 chaetigers ( $1 \mathrm{~mm}$ long) and 21 chaetigers (1.1 mm long). All their segments have similar shape and size; division of the body into regions is detectable only by location and types of chaetae which are similar to those in adults (Figs. 2 I, 3A). The prostomium bears a massive prototroch located on its thickened posterior part (Fig. 3A). The pygidium is split longitudinally by a median fissure and does not have any cirri or appendages (Fig. 3B).

A specimen with 30 chaetigers does not bear the prototroch. It has everted ciliated pharynx partially divided into two halves, but without developed tentacles (Fig. 3D). The body is divided into three regions, with 11 thoracic, 13 abdominal and 7 posterior chaetigers. The pygidium bears 3 long cirri and 6 low triangular appendages (Fig. 3C).
Size structure. The demographic structure was analyzed using the body width in area of branchial filament as an index of size. The median value of body width ranged from 0.125 $\mathrm{mm}$ in July 1998 to $0.200 \mathrm{~mm}$ in August 2000, October 1998 and November 1999. Minimal and maximal body size are also lower in July 1998. Size-frequency histogram (Fig. 4) shows a bimodal distribution, with two size classes each having normal distribution.

\section{Discussion}

\section{Taxonomic affiliation}

The main taxonomic characters which may be used for identifying cossurids are the segment of insertion of dorsal filament, the number of uniramous segments, the types of chaetae, the number of thoracic segments and the structure of the pygidium (Fournier, Petersen, 1991; Read, 2000). Combination of these characters clearly indicates that the WS specimens belong to $C$. pygodactylata, species described from San Francisco Bay (Jones, 1956) and reinvestigated by Bachelet and Laubier (1991). The main difference between $C$. pygodactylata and C. longocirrata (species which WS specimens were previously referred to) is pygidium structure. Both species have three long anal cirri, and C. pygodactylata bears additional 12-20 intercirral processes or papillae (Fournier, Petersen, 1991; Bachelet, Laubier, 1991), whereas C. longocir- 

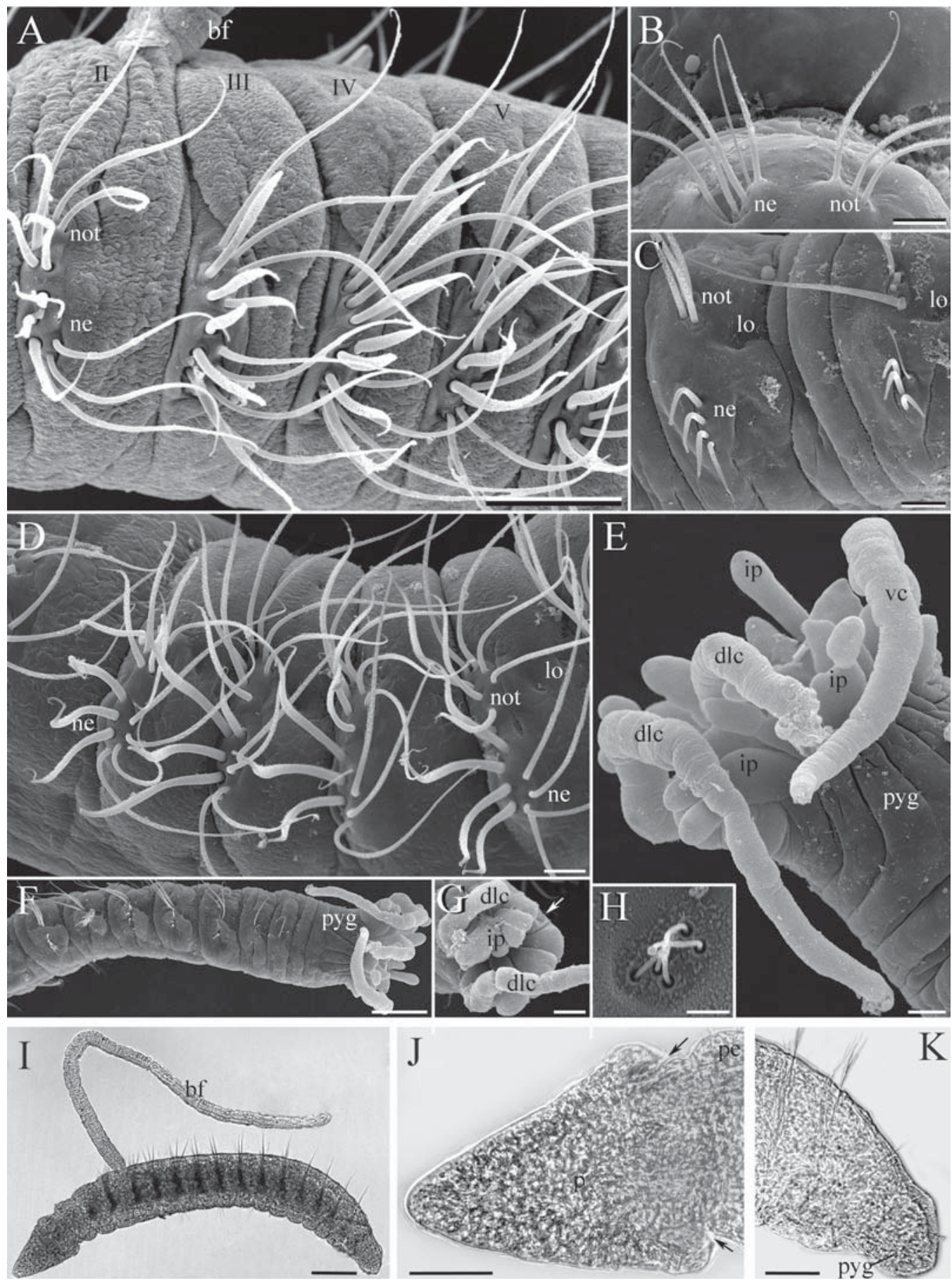

Fig. 2. Cossura pygodactylata.

A-H - adult specimens, SEM. A - anterior thorax, lateral view; B - abdominal chaetiger, anterior view; C - two abdominal chaetigers, lateral view; D - middle thorax, lateral view showing $\mathrm{C}$-shaped arrangement of chaetae; E adult specimen, pygidium, lateral view; F - same specimen, posterior part, lateral view; G - younger specimen, 
pygidium, posterior view, ventral anal cirrus is broken, arrow indicates its scar; $\mathrm{H}$ - lateral organ; I-K - -14 -chaetiger juvenile; photos made with light compound microscope; I - general lateral view; $\mathrm{J}$ - head, arrows indicate location of prototroch; $\mathrm{K}$ - posterior part of body. II-V — chaetiger numbers, bf — branchial filament, dlc — dorso-lateral anal cirrus, ip — intercirral anal processes, lo - lateral organ, ne - neuropodium, no — nuchal organ, not — notopodium, $\mathrm{p}$ - prostomium, pe - peristomium, pyg - pygidium, vc - ventral anal cirrus. Scales: A - $60 \mu \mathrm{m}, \mathrm{B}-\mathrm{E}, \mathrm{G}-20$ $\mu \mathrm{m}, \mathrm{H}-2 \mu \mathrm{m}, \mathrm{I}-100 \mu \mathrm{m}, \mathrm{J}, \mathrm{K}-50 \mu \mathrm{m}$.

Рис. 2. Cossura pygodactylata.

А-Н - взрослые особи, СЭМ. А - передняя часть торакса, вид сбоку; В - сегмент абдомена, вид спереди; $\mathrm{C}$ - два абдоминальных сегмента, вид сбоку; D - средняя часть торакса, вид сбоку, показывающий С-образное расположение щетинок; E - пигидий, вид сбоку; F — задняя часть тела, вид сбоку; G - пигидий, вид сзади, брюшной анальный усик обломан, стрелка указывает на место его прикрепления; Н — латеральный орган; IK - 14-сегментная ювениль; фотографии, сделанные с помощью светового микроскопа; I - общий вид сбоку; $\mathrm{J}$ - голова, стрелки показывают расположение протороха; K - задняя часть тела. II-V — номера щетинконосных сегментов, bf - жаберный филамент, dlc - дорсо-латеральный анальный усик, ip — анальные выросты, lo — латеральный орган, ne - невроподия, no - нухальный орган, not - нотоподия, p - простомиум, pe перистомиум, pyg - пигидий, vc - брюшной анальный усик. Масштаб: А - 60 мкм, B-E, G - 20 мкм, H2 мкм, I - 100 мкм, J, K - 50 мкм.

rata bears none. Besides, C. longocirrata has thicker thoracic chaetae than C. pygodactylata (6-12 vs 3-5 $\mu \mathrm{m}$, respectively). Specimens studied in the present work have up to 14 intercirral pygidial processes; their thoracic chaetae are less than $5 \mu \mathrm{m}$ wide and definitely should be referred to C. pygodactylata.

Bachelet and Laubier (1991) investigated extensive material of $C$. pygodactylata from Bay of Biscay, English Channel (North Eastern Atlantic), specimens from Eastern North Pacific, Western North Atlantic and reexamined the type material of the species. All studied worms have single uniramous chaetiger, dorsal branchial filament inserted on posterior margin of chaetiger 2, 13-21 thoracic chaetigers and pygidium with 10-20 intercirral processes. Some intraspecific variability was indicated: the holotype has closely arranged parapodial rami in six anterior chaetigers whereas in specimens from France and Spain parapodial rami are widely arranged. The corresponding characters of the WS specimens are consistent with this description of $C$. pygodactylata by Bachelet and Laubier (1991), in chaetal arrangement they are most similar with specimens from France.

Prostomium-peristomium delineation in cossurids is a subject of discussions (Jones, 1956; Fournier, Petersen, 1991; Read, 2000). The prostomial-peristomial region usually appears to have two transverse furrows dividing it into three parts and which one marks the border between prostomium and peristomium is uncer- tain. The present study shows that fully relaxed individuals have only one furrow in this region; the second furrow, when it appears due to prostomium contraction, goes through nuchal organs which are found not on the posterior border of the prostomium as in many other polychaetes but shifted anteriorly. The posterior border of the prostomium is marked by the prototroch in juvenile specimens. Thus the anterior furrow when present divides the prostomium into two parts. This statement confirm Jones (1956) and Fournier \& Petersen (1991) point of view.

Tzetlin (1994) described the feeding apparatus of Cossura from the WS. According to his data, the feeding structures are ciliated buccal tentacles attached to the dorsal surface of the buccal cavity; there are about 15 tentacles visible on cross sections. In contrast to those data specimens studied in the present work as well as C. pygodactylata investigated by Bachelet and Laubier (1991) have 4-10 tentacles. Juveniles have simple ciliated pharynx similar to dorsal pharynx of some opheliids (Tzetlin, Zhadan, 2009).

Lateral organs were indicated in many sedentary polychaete families. As a rule they represent densely ciliated areas, pits or papillae present segmentally between the neuro- and notopodia (Purschke, Hausen, 2007). Lateral organs are described in Cossuridae for the first time here. Having typical appearance as ciliated pits they occupy unusual position behind parapodia unlike other polychaetes. 


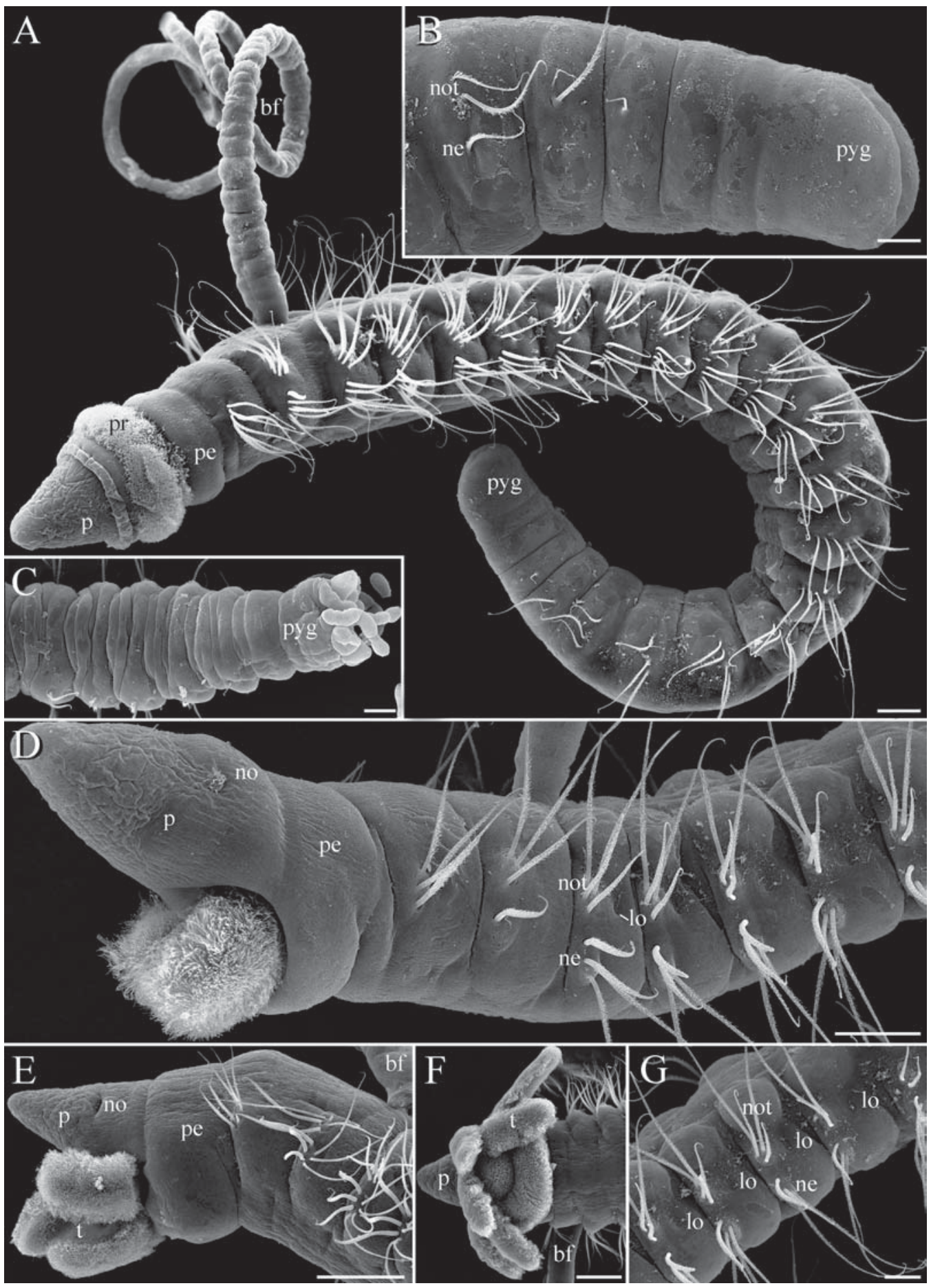

Fig. 3. Cossura pygodactylata, juvenile specimens, SEM.

A - entire 21-chaetiger specimen, lateral view; B - same specimen, posterior part of body, lateral view; C - 30chaetiger specimen, posterior part of body, dorsal view; D - same specimen, anterior part of body, lateral view, note 
location of mouth opening and unbranched pharynx; E - specimen with three pairs of mouth tentacles not completely divided, anterior part, lateral view; F — specimen with three pairs of mouth tentacles, ventral view, note ciliated buccal cavity; G — middle thorax, lateral view. bf — branchial filament, lo — lateral organ, ne — neuropodium, no — nuchal organ, not - notopodium, $\mathrm{p}$ - prostomium, pe - peristomium, pr - prototroch, pyg - pygidium. Scales: A, D $30 \mu \mathrm{m}, \mathrm{B}-10 \mu \mathrm{m}, \mathrm{C}, \mathrm{G}-20 \mu \mathrm{m}, \mathrm{E}, \mathrm{F}-100 \mu \mathrm{m}$.

Рис. 3. Cossura pygodactylata, ювенильные экземпляры, СЭМ.

А - 21-сегментная особь, вид сбоку; В - та же особь, задний конец тела, вид сбоку; С - 30- сегментная особь, задний конец тела, вид со спинной стороны; D - та же особь, передняя часть тела, вид сбоку, видно положение ротового отверстия и не разделенная на щупальца глотка; E - экземпляр с тремя парами не полностью разделенных ротовых щупалец, передняя часть, вид сбоку; F - экземпляр с тремя парами ротовых щупалец, вид с брюшной стороны, видна ротовая полость, покрытая ресничками; $\mathrm{G}$ - средняя часть торакса, вид сбоку. bf жаберный филамент, lo - латеральный орган, ne - невроподия, no - нухальный орган, not - нотоподия, p простомиум, pe - перистомиум, pr - прототрох, pyg - пигидий. Масштаб: A, D - 30 мкм, B - 10 мкм, C, G 20 мкм, E, F - 100 мкм.

\section{Reproduction and larval development}

Gametogenesis of the WS cossurids was studied by Rouse and Tzetlin (1997). Mature gametes as well as different studies of gametogenesis occur in abdominal body cavity of specimens collected in summer. According to their data "mature sperm have a spherical head, a conical acrosome and a simple midpiece. This morphology is typically seen in species using external fertilization and thus the sperm are probably classifiable as ect-aquasperm, though this should be confirmed." Mature oocytes are $100-130 \mu \mathrm{m}$ in diameter, often have irregular shape. Their proportions are close to oocyte size of C. pygodactylata from the Bay of Biscay $(140 \mu \mathrm{m})$. The most probably this species breeds there between February and April (Bachelet, Laubier, 1991). C. longocirrata has smaller oocyte size - 75-35 $\mu \mathrm{m}$, although it can depend on developmental stage of oocytes (Fournier, Petersen, 1991). Little else is known about reproduction of Cossuridae, and no data are available on fertilization mechanisms or larval development except for some data on early juvenile stages of $C$. pygodactylata (Bachelet, Laubier, 1991). The smallest benthic juvenile was $245 \mu \mathrm{m}$ long and $65 \mu \mathrm{m}$ wide, had only four chaetigers, developed branchial filament, but no division of the body into regions. Bigger juveniles had thoracic and abdominal segments distinguished by number, direction and types of chaetae. The pygidium of juveniles was devoid of anal cirri and intercirral appendages. The smallest specimens with both pygidial cirri and intercirral papillae were 26-chaetigers long (Bachelet, Laubier, 1991). Our data on morphology of juveniles correspond well to foregoing information. The important addition obtained in the present study is the occurrence of a prototroch in juveniles with 14-21 chaetigers. The prototroch is most likely represents a larval organ remaining in bigger specimens.

It is unknown whether cossurids have a pelagic stage during ontogenesis. Benthic juveniles of Cossura consimilis Read, 2000 have very long capillary chaetae that may indicate the occurrence of a semi-planktonic dispersal phase (Read, 2000). Juvenile specimens of Cossura sp. bearing very long fine larval capillaries were found in plankton samples from the $0-50 \mathrm{~m}$ layer in the Northeast Pacific (Berkeley, Berkeley, 1960). Juveniles of C. pygodactylata from the White Sea as well as from France have short chaetae and were never found in plankton samples. The most probably this species has direct development without planktonic stage.

\section{Population structure and lifespan}

Bimodal distribution in size-frequency histogram indicates presence of two size classes; the most probably they are two generations juveniles and adults. It can be supposed that lifespan of C. pygodactylata in the WS is at least two years. This fact needs to be confirmed by more studies of the population size structure in different seasons. Presence of small juveniles in all samples may also indicate continuous reproduction during the year. 


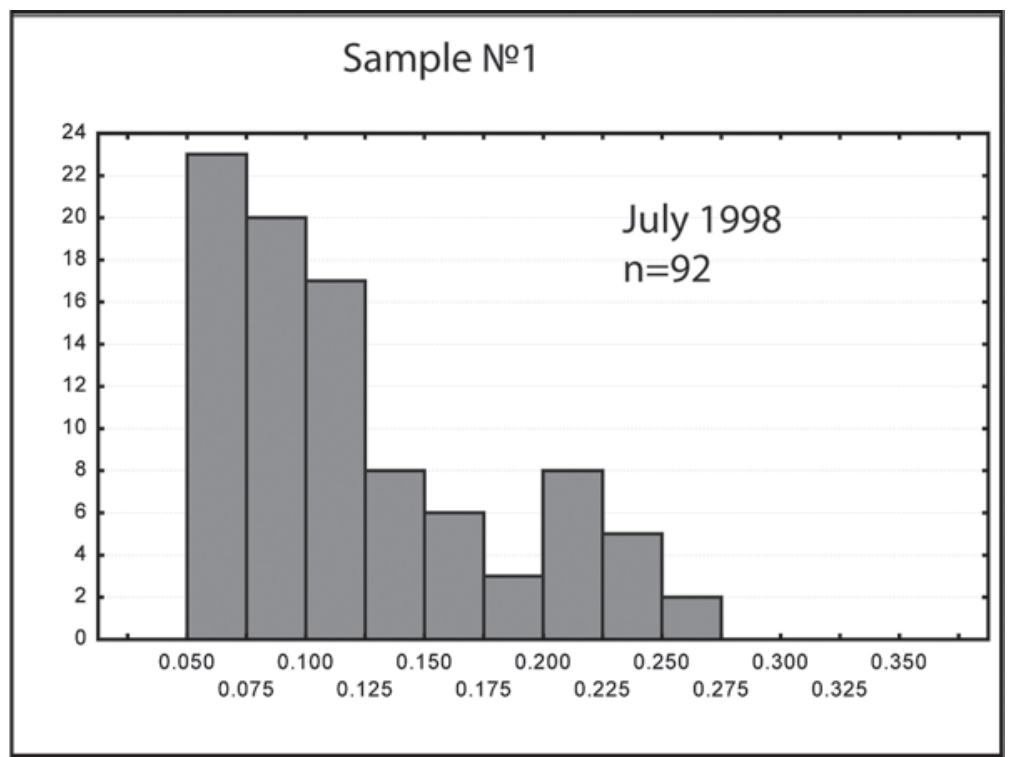

Fig. 4. Cossura pygodactylata, size-frequency histogram characterizing sample obtained in July, 1998. $\mathrm{X}$-axis — body width, mm; Y-axis — number of specimens.

Рис. 4. Cossura pygodactylata, размерно-частотная гистограмма, характеризующая структуру популяций в пробе, взятой в июле 1998 г.

Х-ось - ширина тела, мм; Ү-ось — число экземпляров.

\section{Geographical distribution}

C. pygodactylata inhabits Eastern North Pacific (California, British Columbia), NorthWestern Pacific (Japan) as C. lepida Tamai, 1986 (synonymized with C. pygodactylata by Hilbig (1996)), Western and Eastern North Atlantic (West Greenland, English Channel, Bay of Biscay, Spanish Basque coast) (Fournier, Petersen, 1991; Bachelet, Laubier, 1991). It occurs in muddy sediment, usually in shallow water $(1-30 \mathrm{~m})$, but in some locations up to $2720 \mathrm{~m}$ (Hilbig, 1996). Our study extends its distribution to the White Sea, where it inhabits muddy sediment in the depth range 20-300 m.

\section{Acknowledgements}

We are greatly indebted to the master and crew of R/V "Kartezh" participants of cruises 1998-2001 yr. The present study was supported by the Russian Foundation for Basic Research, projects \#\# 11-04-01695, 10-04-01547, and federal target program of the Ministry of Education and Science of Russian Federation.

\section{References}

Annenkova N.P. 1938. [Polychaeta of the North Japan Sea and their horizontal and vertical distribution. Hydrobiol. Exped. U.S.S.R. in 1934 to the Japan Sea] // Trudy D.-V. filiala Akademii Nauk SSSR. Vol.1. P.81-230 [in Russian].

Bachelet G., Laubier L. 1994. Morphology, ecology and juvenile development of Cossura pygodactylata Jones (Polychaeta, Cossuridae) in Arcachon Bay, SW France, with a reassessment of the geographical distribution of C. pygodactylata and C. soyeri Laubier// Mémoires du Muséum National d'Histoire Naturelle, Paris. Vol.162. P.355-369.

Berkeley E., Berkeley C. 1960. Some further records of pelagic polychaeta from the Northeast Pacific north of latitude $40^{\circ} \mathrm{N}$. and east of longitude $175^{\circ} \mathrm{W}$., together with records of Siphonophora, Mollusca, and Tunicata from the same region // Canadian Journal of Zoology. Vol.38. P.787-799.

Fournier J.A., Petersen M.E. 1991. Cossura longocirrata: Redescription and distribution, with notes on reproductive biology and a comparison of described spe- 
cies of Cossura (Polychaeta: Cossuridae) // Ophelia Supplement 5 P.63-80.

Gardiner S.L., Wilson W.H., Jr. 1977 [1979]. New records of polychaete annelids from North Carolina with the description of a new species of Sphaerosyllis (Syllidae) // Journal of the Elisha Mitchell Scientific Society. Vol.93 P.159-172.

Jones M.L. 1956. Cossura pygodactylata, a new annelid from San Francisco Bay (Polychaeta: Cirratulidae) // Journal of the Washington Academy of Sciences. Vol.46. No.4. P.127-130.

Hilbig B. 1996. Family Cossuridae Day, 1963 // Taxonomic atlas of the benthic fauna of the Santa Maria Basin and western Santa Barbara Channel. Vol. 6. The Annelida. Part 3. Polychaeta: Orbiniidae to Cossuridae. Santa Barbara Museum of Natural History, Santa Barbara. P.385-404.

Naumov A.D., Fedyakov V.V. 2000. New results on the macro- zoobenthos of the White Sea deep basin: Part 2. Small benthic organisms and juveniles of macrobenthic species in the White Sea deep- water assemblage // Reports on Polar Research. Alfred-WegenerInstitut für Polar- und Meeresforschung publ. Vol.359 P.72-97.

Read G.B. 2000. Taxonomy and distribution of a new Cossura species (Annelida: Polychaeta: Cossuridae) from New Zealand // Proceedings of the Biological Society of Washington. Vol.113. No.4. P.1096-1110.

Rouse G.W., Pleijel F. 2001. Polychaetes. Oxford: Oxford University Press. 354 pp.

Rouse G.W., Tzetlin A.B. 1997. Ultrastructure of the body wall and gametogenesis in Cossura cf. longocirrata (Cossuridae Polychaeta) // Invertebrate Reproduction and Development. Vol.32. P.41-54.
Purschke G., Hausen H. 2007. Lateral organs in sedentary polychaetes (Annelida) - Ultrastructure and phylogenetic significance of an insufficiently known sense organ // Acta Zoologica (Stockholm) Vol.88. P.23-39.

Tamai K. 1986. Two new species of Cossura (Polychaeta, Cossuridae) from western Japan // Bulletin of the National Science Museum Series (Zoology) Vol.12. P.155-161.

Tzetlin A.B. 1980. [Practical key of Polychaeta of the White Sea]. Moscow: MGU Publ. 113 p. [in Russian]

Tzetlin A.B. 1994. Fine morphology of the feeding apparatus of Cossura sp. (Polychaeta, Cossuridae) from the White Sea // Mémoires du Muséum National d'Histoire Naturelle, Paris. Vol.162. P.137-143.

Tzetlin A.B., Zhadan A.E. 2008. [Class Polychaeta Grube 1850. Polychaetous worms] // Tschesunov A.V., Kalyakina N.M., Bubnova E.N. (eds.). Katalog bioty Belomorskoi Biologicheskoi stantsii MGU. Moscow: KMK Sci. Press Ltd. P.240-248 [in Russian].

Tzetlin A.B., Zhadan A.E. 2009. Morphological variation of axial non-muscular proboscis types in the Polychaeta // Zoosymposia. Vol.2. P.415-427.

Uschakov P.V. 1955. P[olychaeta of the far eastern seas of the U.S.S.R.] Moscow \& Leningrad: Izdatel'stvo Akademii Nauk SSSR. 445 p. [in Russian].

Webster H.E., Benedict J.E. 1887. The Annelida Chaetopoda from Eastport, Maine // U.S. Commission of Fish \& Fisheries. Report of the United States Commissioner of Fisheries. (Appendix D. 12). Vol.1885. P.707-755.

Zatsepin V.I. 1948. [Polychaeta] // Gaevskaya N.S. (ed.). Opredelitel' fauny i flory severnykh morei SSSR. Moscow: Sovetskaya Nauka Publ. P.94-167 [in Russian].

Responsible editor E.N. Temereva 